\title{
NUTRITIONAL STATUS OF PATIENTS WITH BILIARY ATRESIA AND AUTOIMMUNE HEPATITIS RELATEDTO SERUM LEVELS OF VITAMINS A, D AND E
}

\author{
Margareth L. G. SARON¹, Helena T. GODOY² and Gabriel HESSEL'1
}

\begin{abstract}
Context - Chronic liver disease may induce to malabsorption of lipids and fat-soluble vitamins, leading to injury of nutritional status. Objectives - To evaluate the nutritional status of pediatric-age patients with autoimmune hepatitis and biliary atresia related to serum levels of vitamins A, D and E and the disease severity. Methods - This controlled transverse study, evaluated the patients with autoimmune hepatitis and biliary atresia and a reference group paired by sex and age. The patients underwent anthropometric evaluation, alimentary inquiry and determination of serum levels of vitamins A, D and E by high performance liquid chromatography. The Mann-Whitney test, Spearman correlation coefficients and variance analysis (ANOVA) were utilized for data treatment, regarding significant difference if $P<0.05$. Results - The highest nutritional deficit was observed in patients with biliary atresia, mainly with cholestasis. The serum levels of vitamins $\mathrm{A}$ and $\mathrm{E}$ for the reference group changed as a function of age. The serum levels of vitamins $\mathrm{A}, \mathrm{D}$ and $\mathrm{E}$ were higher in reference group than in patients with biliary atresia and autoimmune hepatitis together or separately. There were not difference in the serum levels of vitamins $\mathrm{A}, \mathrm{D}$ and $\mathrm{E}$ between biliary atresia groups with cholestasis and without cholestasis. It was verified correlation between weight/age, triceps skinfold thickness, subscapular skinfold thickness, midarm circumference, midarm fat area values and vitamin A serum levels, as well as between all anthropometric indicators and vitamin $\mathrm{E}$ in patients with autoimmune hepatitis and biliary atresia. Conclusion - The patients with biliary atresia and cholestasis presented the highest nutritional injury. The patients with biliary atresia and autoimmune hepatitis presented lower serum levels of vitamins A, D and $\mathrm{E}$ that in control group. There is a directly proportional correlation between vitamin serum levels, mainly vitamin $\mathrm{E}$, and all anthropometric variables of biliary atresia and autoimmune hepatitis groups.
\end{abstract}

HEADINGS - Nutritional status. Fat soluble vitamins. Biliary atresia. Hepatitis, autoimmune. Child.

\section{INTRODUCTION}

Cholestasis is an impediment of the biliary channel flow, independently of the site where is located the obstacle or cause that determines the obstruction ${ }^{(37)}$. Nutritional deficiencies are frequent in children and adults with chronic liver disease (CLD), mainly infant cholestasis ${ }^{(3,38)}$

Energetic-protein malnutrition affects approximately $60 \%$ of children with chronic hepatopathy ${ }^{(34)}$, and this is associated with increase in morbidity and mortality rates. It is a complication that has some important implications for prognosis ${ }^{(18)}$.

Conventional methods to measure nutritional status may not always be applicable for patients with CLD. The uncontrolled hepatic function may change body weight, plasmatic protein production, immune function and determinations of the individual body tissue compartment, independently of nutritional status. Thus, the body weight is usually an uncertain indicator of nutritional status for patients with CLD due to fluid retention, edema and ascites. Midarm circumference and triceps skinfold thickness are preferred alternative parameters to detect malnutrition in adults and children with CLD ${ }^{(25)}$.

Different mechanisms may contribute to malnutrition, such as decrease in dietary ingestion due to anorexia, malabsorption of long chain triglycerides that conduces to fat-soluble deficiency and essential fatty acids, abnormal nitrogen metabolism with aromatic amino acid increase, branched-chain amino acid decrease and changes in substrate utilization, conducing to reduction in fat storage and negative protein balance ${ }^{(28)}$.

It is frequent the deficiency of fat-soluble vitamins in CLD, mainly in the presence of cholestasis ${ }^{(38)}$. The deficiency in absorption, mobility and storage are factors that cause decrease in vitamin A serum levels. Night blindness is a frequent damage caused by vitamin A deficiency. Vitamin D deficiency is another consequence of CLD, resulting primarily from malabsorption. The low

This study was conducted by the ${ }^{1}$ Department of Pediatrics and ${ }^{2}$ Faculty of Food Engineering, "Universidade Estadual de Campinas" - UNICAMP, Campinas, SP, Brazil.

Correspondence: Prof. Gabriel Hessel - Departamento de Pediatria - FCM-UNICAMP - C.P. 6111 - 13083-970 - Campinas, SP, Brazil. E-mail: ghessel@fcm.unicamp.br 
exposition to solar light and the inadequate dietary ingestion may also contribute to this vitamin deficiency ${ }^{(18)}$. Vitamin $\mathrm{E}$ is the main antioxidant responsible for protecting the membranes against lipid peroxidation. In humans, vitamin E deficiency may cause neurological dysfunction, myopathies and decreased erythrocyte life ${ }^{(40)}$.

Biliary atresia (BA) is a more frequent cause of chronic cholestasis and the main indication of pediatric hepatic transplants ${ }^{(24)}$. It is characterized by an inflammatory destructive process that affects intrahepatic and extrahepatic biliary ducts, conducing to fibrosis and biliary tract obliteration from some point of the porta hepatis to the duodenum ${ }^{(4)}$.

On the other hand, autoimmune hepatitis (AIH) is another disease that affects predominantly hepatocytes. This disease is considered a form of chronic hepatitis of etiology unknown that affects patients who have lost the immunologic tolerance to liver antigens ${ }^{(9)}$. The diagnostic is based in presence of clinic and laboratorial discovery and exclusion of others causes of chronic hepatic diseases ${ }^{(21)}$.

In agreement with the literature, the patients with BA and $\mathrm{AIH}$ tend to present nutritional and fat-soluble vitamin deficits ${ }^{(3,39)}$. However, the relation between nutritional deficit and fat-soluble vitamin deficiency in these diseases is not cleared yet. Thus, the aim of this study was to verify the relation between the nutritional status of pediatric-age patients with biliary atresia and autoimmune hepatitis, the serum levels of vitamins A, D and $\mathrm{E}$ and the disease severity.

\section{METHODS}

The research was carried out at the Ambulatory Department of Pediatric Hepatology of the University Hospital, Faculty of Medical Sciences, State University of Campinas (UNICAMP) and Ambulatory Department of Pediatric Hepatic Transplants of the Gastroenterology Center (GASTROCENTER-UNICAMP), Campinas, SP, Brazil, between January 2004 and August 2006. The controlled transverse study was approved by the Institutional Review Board of the Faculty of Medical Sciences (FCM) of UNICAMP, protocol 542/2003. Parents and responsible for the patients signed the free and clarified consent terms.

Patients between 4 months and 17.9 years of age diagnosed with BA and AIH were evaluated. The BA diagnosis was obtained by hepatic biopsy and surgical procedures. The scoring system established by the International Autoimmune Hepatitis Group was used for AIH diagnosis ${ }^{(2)}$. The exclusion criteria were the use of vitamins A, D and E by injection during the last 3 months, use of parenteral nutrition during the last 3 months and refusal to sign the free and clarified consent term by parents or people responsible for patients. Thus, 49 patients with CLD were selected -25 presented AIH and 24 BA.

The patients were classified as cholestatic and noncholestastic in accordance with the criteria established by MOYER et al. ${ }^{(27)}$. The AIH and BA groups were separated according to the level of hepatopathy, using the Child-Pugh classification $^{(35)}$. Although this method has been used for patients with cirrhosis, it is known that almost always patients with BA and AIH present cirrhosis ${ }^{(1,41)}$. For statistical analysis, the patients with Child B and Child $\mathrm{C}$ were grouped. Eleven Child class A patients and 13 Child class B + Child class C patients in the BA group were classified, while 19 Child class A patients and 6 Child class $B+$ Child class $C$ patients in the AIH group were classified.

The control group was comprised patients with recurrent abdominal pain, chronic intestinal constipation or strabismus assisted at the Pediatric Gastroenterology and Nutrition Service and Ophthalmology Service of the FCM-UNICAMP. The inclusion criteria were being within the same chronological age group of patients of the study (maximum variation \pm 5 months) and presenting $\mathrm{Z}$ score of weight and height between +2 and -2 for age and sex, according to the Center for Disease Control ${ }^{(7)}$. The exclusion criteria were presence of diarrhea and fever, the non-signature of the free and clarified consent term by parents or responsible for the patients, or evidence of chronic hepatopathy verified by clinical history, physical exams or report review. By using these criteria, 53 patients were selected (39 females and 14 males) with median age of 7.6 years, varying between 0.7 and 17.6 years.

\section{Determination of serum levels of fat-soluble vitamins}

Blood samples of volume between 2 and $5 \mathrm{~mL}$ were collected by puncture of peripheral vein, above that amount usually collected for routine exams. The extraction of vitamins A, D and E was performed according to the methodology described by WANG and $\mathrm{HUANG}^{(42)}$. The separation and quantification of the serum fat-soluble vitamins were carried out by high performance liquid chromatography (HPLC). All-trans-retinol (Sigma $\left.{ }^{\circledR}\right)$, cholecalcipherol $\left(\right.$ Sigma $\left.^{\circledR}\right)$ and D-L- $\alpha$-tocopherol $\left(\right.$ Merck $^{\circledR}$ ) were used as reference standards for analysis.

\section{Anthropometry and body composition}

The anthropometric measures used in this study were body weight and body length or stature according to LOHMAN et al. technique ${ }^{(19)}$. Weight and stature data were used to calculate the body mass index (BMI), which is obtained dividing body weight by the square of stature.

Weight, height and BMI values were converted to Z-score using the system for anthropometric data analysis SISCRES (Growth Data Analysis System-FCM-UNICAMP) which utilizes the growth curve of the Center for Disease $\mathrm{Control}^{(7)}$ for gender and age.

The body composition was determined by midarm circumference and skinfold, according to the procedures described by LOHMAN et al. ${ }^{(19)}$. The anthropometric measures for all patients always were obtained by the same examiner. The medium value of three measures was used as final value.

Anthropometric parameters and body composition were not considered in patients that presented edema or ascites, except for stature/age. Using values obtained from triceps skinfold thickness and midarm circumference, the derivative measures were calculated: midarm muscle area and midarm fat area, according to studies by FRISANCHO ${ }^{(14)}$. 
Values of skinfold, skinfold sum, midarm muscle area and midarm fat area were converted for Z score using the SISCRES software, according to the Frisancho curve ${ }^{(15)}$ for skinfold.

\section{Dietary inquiry}

The dietary inquiry was applied as habitual reminder to mothers or people responsible for the patients ${ }^{(11)}$. For calculus of energetic ingestion and macronutrients, alimentary register information was analyzed by the Dietpro software, version 4 . The energy adequacy values were used in agreement with the recommendations of Dietary Reference Intake ${ }^{(10)}$ as reference standart for healthful individuals, increasing $30 \%$ for patients with $\mathrm{BA}$, according to PIERRO et al. ${ }^{(33)}$, and $30 \%$ for patients with $\mathrm{AIH}$, according to recommendations for chronic hepatic disease ${ }^{(6)}$.

\section{Data analysis}

Statistical treatment of results was performed by using the SPSS software (Statistical Package for Social Science). The nonparametric Mann-Whitney test was used to compare the continuous variable for the two groups. The linear correlation analysis among variables of the groups of patients was conducted using the Spearman's correlation coefficient ${ }^{(36)}$. Variance analysis $(\text { ANOVA })^{(8)}$ was used to compare three or more groups. Significance was established at $P \leq 0.05$ in all tests.

\section{RESULTS}

The AIH group comprised 21 females and 4 males with median age of 12.5 years, varying between 5 and 17.9 years; while the BA group comprised 14 females and 10 males with median age of 3.2 years, varying between 0.3 and 13.9 years. The Mann-Whitney test showed age difference between the groups $(P=0.0001)$.

The results of BA and $\mathrm{AIH}$ anthropometric evaluation are presented in Table 1.

It was observed that the median of Z-score values of the variables follow the normality levels of values for the AIH group. However, the minimum values in the BA group are found below Z-score-2, presenting a serious nutritional deficit when compared with patients with AIH for the variables weight/age, body mass

TABLE 1. Results of nutritional evaluation using Z-score for BA (biliary atresia) and $\mathrm{AIH}$ (autoimmune hepatitis) groups

\begin{tabular}{|c|c|c|c|c|c|}
\hline Z-Score & $\mathrm{N}$ & BA & $\mathbf{N}$ & AIH & $P^{*}$ \\
\hline & & Median $(\min . / \max )$. & & Median (min./max.) & \\
\hline Weight/age & 18 & $-0.12(-4.88 / 1.69)$ & 22 & $0.58(-1.92 / 2.72)$ & 0.017 \\
\hline Stature/age & 24 & $-0.11(-3.50 / 1.42)$ & 25 & $0.02(-2.48 / 4.77)$ & 0.542 \\
\hline Body mass index & 18 & $0.36(-3.23 / 1.65)$ & 22 & $0.94(-1.08 / 2.32)$ & 0.040 \\
\hline $\begin{array}{l}\text { Midarm } \\
\text { circumference }\end{array}$ & 18 & $-1.16(-3.81 / 1.36)$ & 22 & $0.82(-1.89 / 1.85)$ & 0.001 \\
\hline $\begin{array}{l}\text { Triceps skinfold } \\
\text { thickness }\end{array}$ & 18 & $-1.55(-3.36 / 0.05)$ & 22 & $0.28(-1.65 / 2.40)$ & 0.001 \\
\hline $\begin{array}{l}\text { Subscapular skinfold } \\
\text { thickness }\end{array}$ & 18 & $0.14(-3.77 / 2.19)$ & 22 & $0.47(-0.55 / 2.49)$ & 0.072 \\
\hline Midarm muscle area & 13 & $-0.22(-4.00 / 2.81)$ & 22 & $0.30(-2.01 / 3.82)$ & 0.065 \\
\hline Midarm fat area & 13 & $-1.15(-2.57 / 0.27)$ & 22 & $0.56(-1.80 / 3.14)$ & 0.001 \\
\hline Skinfold sum & 13 & $-0.76(-2.54 / 0.73)$ & 22 & $0.37(-1.37 / 2.55)$ & 0.022 \\
\hline
\end{tabular}

$\mathrm{N}=$ absolute number; Median (minimum and maximum); * Mann-Whitney test index, midarm circumference, triceps skinfold thickness, midarm fat area and skinfold sum, with statistical significance. Six BA patients and three AIH patients were diagnosed with ascites. Only the stature/age measure was used for diagnosis; the other anthropometric measures were excluded.

When the BA group was divided into two other groups of patients, according to presence and absence of cholestasis, the group presenting cholestasis showed a more serious nutritional deficit for the variables weight/age, stature/age, body mass index, midarm circumference, triceps skinfold thickness, with statistical significance (Table 2).

TABLE 2. Results of anthropometric evaluation using Z-score for BA (biliary atresia) groups with presence or absence of cholestasis

\begin{tabular}{|c|c|c|c|c|c|}
\hline \multirow[b]{2}{*}{ Z-Score } & \multicolumn{5}{|c|}{ Cholestasis } \\
\hline & $\mathbf{N}$ & Presence & $\mathbf{N}$ & Absence & $P^{*}$ \\
\hline & & Median (min./max.) & & Median (min./max.) & \\
\hline Weight/age & 9 & $-1.67(-4.88 / 1.58)$ & 9 & $0.54(-0.55 / 1.69)$ & 0.007 \\
\hline Stature/age & 14 & $-0.55(-3.50 / 0.70)$ & 10 & $0.40(-0.56 / 1.42)$ & 0.009 \\
\hline Body mass index & 9 & $-0.95(-3.23 / 1.65)$ & 9 & $0.89(-0.79 / 1.62)$ & 0.038 \\
\hline $\begin{array}{l}\text { Midarm } \\
\text { circumference }\end{array}$ & 9 & $-2.19(-3.81 /-0.91)$ & 9 & $-0.81(-1.79 / 1.36)$ & 0.002 \\
\hline $\begin{array}{l}\text { Triceps skinfold } \\
\text { thickness }\end{array}$ & 9 & $-2.06(-3.36 / 0.05)$ & 9 & $-0.94(-3.17 / 0.01)$ & 0.034 \\
\hline $\begin{array}{l}\text { Subscapular } \\
\text { skinfold thickness }\end{array}$ & 9 & $-1.36(-3.77 / 0.71)$ & 9 & $0.29(-2.47 / 2.19)$ & 0.102 \\
\hline
\end{tabular}

During the vitamin analysis, it was verified that the serum levels of vitamins A and E for the control group changed as a function of life stage (Table 3).

TABLE 3. Serum levels of vitamins A, D and E, according to the control group age

\begin{tabular}{|c|c|c|c|c|}
\hline \multirow{2}{*}{$\begin{array}{c}\text { Age } \\
\text { (years) }\end{array}$} & \multirow[t]{2}{*}{$\mathbf{N}$} & \multicolumn{3}{|c|}{ Median (min./max.) } \\
\hline & & Vitamin A (ng/dL) & Vitamin D (ng/dL) & Vitamin E (ng/dL) \\
\hline$\leq 3$ & 12 & $\begin{array}{c}90.28^{A}(61.42 / \\
140.57)\end{array}$ & $\begin{array}{c}49.96^{\mathrm{B}}(30.41 / \\
116.87)\end{array}$ & $1489.14^{\mathrm{C}}(1020.13 / 2272.25)$ \\
\hline $4-8$ & 15 & $\begin{array}{c}122.98^{A}(75.54 / \\
179.01)\end{array}$ & $\begin{array}{c}59.39^{\mathrm{B}}(31.44 / \\
111.40)\end{array}$ & $1992.17^{\mathrm{C}}(1342.39 / 5416.45)$ \\
\hline $9-13$ & 14 & $\begin{array}{c}136.49^{A}(104.79 / \\
245.84)\end{array}$ & $\begin{array}{c}52.93^{\mathrm{B}}(21.55 / \\
99.34)\end{array}$ & $2253.35^{\mathrm{C}}(1254.53 / 4031.41)$ \\
\hline $14-18$ & 12 & $\begin{array}{c}154.19^{A}(97.45 / \\
213.78) \\
\end{array}$ & $\begin{array}{c}54.20^{\mathrm{B}}(41.98 / \\
90.95)\end{array}$ & $2354.94^{\mathrm{C}}(1055.90 / 7970.22)$ \\
\hline
\end{tabular}

$\mathrm{N}=$ absolute number; Median (minimum and maximum). ${ }^{\mathrm{A}} \mathrm{ANOVA}: \mathrm{P}=0.0001 \quad \leq 3$ ages $\neq 9-13$ and $14-18$ years old) (4-8 ages $\neq 14-18$ years old); ${ }^{B}$ ANOVA: $P=0.6228$; ${ }^{C}$ ANOVA: $P=0.0232(\leqslant 3$ ages $\neq 9-13$ and 14 -18 years old $)$

The control patients with age under 3 years old presented the lowest serum levels of vitamins $\mathrm{A}$ and $\mathrm{E}$ when compared to the control patients aged 9-13 years old and 14-18 years old. The patients with life stage between 4 and 8 years old presented the lowest serum levels for vitamin A when compared to the patients with life stage between 14 and 18 years old, with statistic significance. While, for vitamin D the results showed that the different life stages did not present significante differences to the serum levels of this vitamin.

The control group was paired by sex and age according to the BA and $\mathrm{AIH}$ groups. Equally, this procedure was used for 
BA and AIH groups separately, variating the individuals number of the control group.

In Table 4 , it is observed that the serum levels of vitamins $\mathrm{A}, \mathrm{D}$ and $\mathrm{E}$ were lesser in patients with $\mathrm{BA}$ and $\mathrm{AIH}$, together or separated than in control group patients, with statistical significance. For the BA group with cholestasis and without cholestasis there was no difference in the serum levels of vitamins $\mathrm{A}, \mathrm{D}$ and $\mathrm{E}$, even in age-corrected values. In the BA group, 14 patients were diagnosed with cholestasis (median age of 1.3 years, varying between 0.3 and 13 years) and 10 presented negative diagnosis of cholestasis (median age of 5.1 years, varying between 0.6 and 13.9 years) with age difference by Mann-Whitney test $(P=0.0324)$. Cholestasis was observed in only four patients of the AIH group.

TABLE 4. Comparison of serum levels of vitamins A, D and E between the hepatopathic patient group and control group

\begin{tabular}{lcccc}
\hline \multirow{2}{*}{ Group } & N & \multicolumn{3}{c}{ Median (ng/dL) } \\
\cline { 3 - 5 } & & Vitamin A & Vitamin D & Vitamin E \\
\hline BA + AIH & 49 & $55.46^{*}$ & $25.11^{*}$ & $787.38^{*}$ \\
Control** & 53 & 128.81 & 56.78 & 2017.33 \\
BA & 24 & $35.51^{*}$ & $26.33^{*}$ & $491.53^{*}$ \\
Control** & 27 & 99.59 & 57.55 & 1679.50 \\
AIH & 25 & $98.42^{*}$ & $24.40 *$ & $1426.48 *$ \\
Control** & 26 & 143.77 & 55.01 & 2438.88 \\
BA with cholestasis & 14 & 35.39 & 31.08 & 526.98 \\
BA without cholestasis & 10 & 54.92 & 34.99 & 602.38 \\
\hline
\end{tabular}

$\mathrm{N}=$ absolute number; $\mathrm{BA}$ (biliary atresia): AlH (autoimmune hepatitis); ${ }^{*}$ Mann-Whitney test, $\mathrm{P}<0.05$;

** Control paired by sex and age

The correlation tests of Z-score indicators for weight/age, stature/age, body mass index, triceps skinfold thickness, subscapular skinfold thickness, midarm circumference, midarm muscle area, midarm fat area, skinfold sum with serum levels of vitamin A, $\mathrm{D}$ and $\mathrm{E}$ are presented in Figure 1.

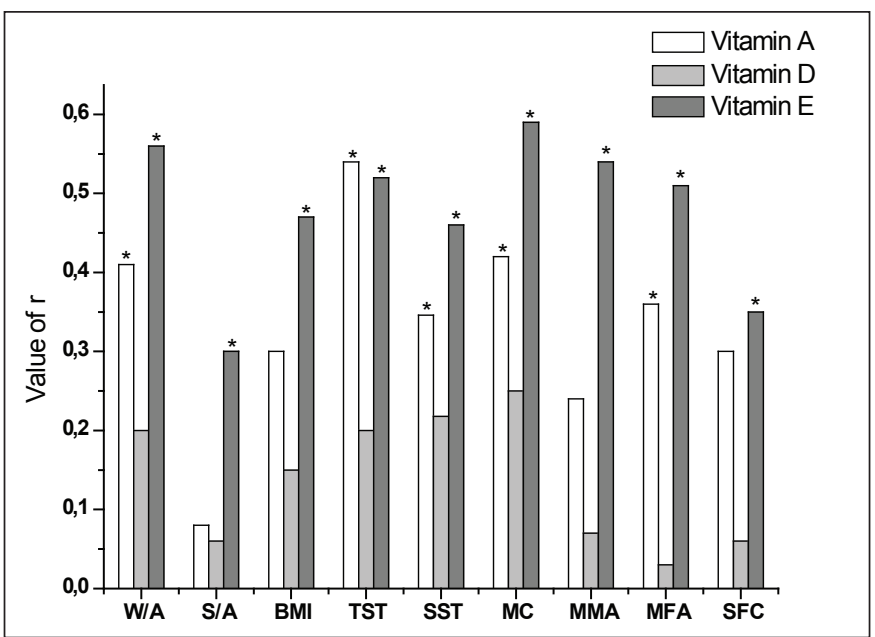

FIGURE 1. Linear correlation ( $\mathrm{r}$ ) of variables weight/age (W/A), stature/age (S/A), body mass index (BMI), triceps skinfold thickness (TST), subscapular skinfold thickness (SST), midarm circumference (MC), midarm muscle area (MMA), midarm fat area (MFA) and skinfold sum (SFC) with serum levels of vitamins $\mathrm{A}, \mathrm{D}$ and $\mathrm{E}$ for patients with biliary atresia and autoimmune hepatitis together. $* P<0.05$
It was observed a significant correlation between weight/age, triceps skinfold thickness, subscapular skinfold thickness, midarm circumference, midarm fat area and vitamin A levels and between all anthropometric indicators and vitamin $\mathrm{E}$ levels in patients with BA and AIH analyzed together.

When the group AIH and BA were analyzed separately, the correlation remained prevalent between vitamin $\mathrm{A}$ and the variables triceps skinfold thickness $(r=0.49)$ and midarm circumference $(r=0.48)$ in the BA group, and the variable skinfold sum $(r=0.30)$ in the AIH group, with statistical significance $(P<0.05)$. There was correlation between vitamin $\mathrm{E}$ and the variables weight/age and midarm circumference in the BA group, and the variable midarm muscle area in the AIH group, with statistical significance $(P<0.05)$.

Considering the disease severity, the BA patients classified as Child $\mathrm{B}+$ Child $\mathrm{C}$ presented the highest nutritional deficits for the variables weight/age, body mass index, midarm circumference, triceps skinfold thickness, subscapular skinfold thickness when compared with BA patients classified as Child A class, with statistical difference (Table 5).

TABLE 5. Comparison between Child A class and Child B class + Child $\mathrm{C}$ class patients with $\mathrm{BA}$ for anthropometric variables

\begin{tabular}{|c|c|c|c|c|c|}
\hline Z-Score & $\mathbf{N}$ & BA Child-Pugh A & $\mathbf{N}$ & BA Child-Pugh B $+C$ & ${ }^{*} \boldsymbol{P}$ \\
\hline & & $\begin{array}{l}\text { Mean } \pm \text { standard } \\
\text { deviation }\end{array}$ & & $\begin{array}{l}\text { Mean } \pm \text { standard } \\
\text { deviation }\end{array}$ & \\
\hline Weight/age & 11 & $0.05 \pm 1.77$ & 7 & $-1.57 \pm 1.05$ & 0.008 \\
\hline Stature/age & 11 & $0.00 \pm 1.29$ & 13 & $-0.743 \pm 1.28$ & 0.093 \\
\hline Body mass index & 11 & $0.40 \pm 1.41$ & 7 & $-0.77 \pm 1.08$ & 0.033 \\
\hline $\begin{array}{l}\text { Midarm } \\
\text { circumference }\end{array}$ & 11 & $-0.74 \pm 1.3$ & 7 & $-2.34 \pm 1.12$ & 0.010 \\
\hline $\begin{array}{l}\text { Triceps skinfold } \\
\text { thickness }\end{array}$ & 11 & $-1.14 \pm 0.94$ & 7 & $-2.23 \pm 1.13$ & 0.041 \\
\hline $\begin{array}{l}\text { Subscapular } \\
\text { skinfold thickness }\end{array}$ & 11 & $0.23 \pm 1.53$ & 7 & $-1.43 \pm 1.15$ & 0.048 \\
\hline
\end{tabular}

$\mathrm{N}=$ absolute number; BA (biliary atresia); * Mann-Whitney test

The AIH patients classified as Child A did not present difference for anthropometric variable when compared with patients classified as Child B + Child C, without statistical significance $(P>0.05)$.

The Table 6 shows the distribution of macronutrients and the energy adequated to the CLD. The lipid percentile was the single parameter with statistical significance, while the ingestion was greater in BA patients than in patients with AIH. The energy adequated to the CLD was lower in AIH patients that in BA patients, with statistical significance.

TABLE 6. Distribution of macronutrients and energy adequated for patients with autoimmune hepatitis $(\mathrm{AIH})$ and biliary atresia $(\mathrm{BA})$

\begin{tabular}{lccc}
\hline & $\begin{array}{c}\text { BA }(\mathbf{N}=24) \\
\text { Median (min./max.) }\end{array}$ & $\begin{array}{c}\text { AIH }(\mathbf{N}=25) \\
\text { Median (min./max.) }\end{array}$ & ${ }^{*} \boldsymbol{P}$ \\
\hline Macronutrients distribution & & & \\
Protein (\%) & $15.29(5.79 / 18.54)$ & $16.75(10.48 / 24.35)$ & 0.177 \\
Carbohydrate (\%) & $50.65(24.81 / 60.10)$ & $54.43(24.45 / 65.83)$ & 0.097 \\
Lipid (\%) & $35.21(21.65 / 56.96)$ & $29.82(15.99 / 58.51)$ & 0.032 \\
Energy adequated to the CLD $(\%)$ & $86.80(42.70 / 204.40)$ & $56.2(30.80 / 102.50)$ & 0.002 \\
\hline
\end{tabular}

$\mathrm{N}=$ absolute number; Median (minimum and maximum); ${ }^{*}$ Mann-Whitney test; $\mathrm{CLD}$ (chronic liver disease) 


\section{DISCUSSION}

The BA patients showed a serious nutritional deficit (weight/age, body mass index, midarm circumference, triceps skinfold thickness, midarm fat area and skinfold sum) in comparison to the AIH patients. Considering the cholestatic and non-cholestatic groups, it was observed that the more serious nutritional deficit (weight/age, stature/age, body mass index, midarm circumference and triceps skinfold thickness) occurred in patients with cholestasis. Similarly, in a study conducted by MATTAR et al. ${ }^{(26)}$, it was also detected the more serious nutritional deficit in patients with cholestasis, predominating the weight/age and stature/age deficits. The triceps skinfold thickness and midarm muscle area could be more sensible indicators of nutritional status for chronic hepatic disease than others anthropometric measures ${ }^{(29)}$.

It is necessary a rigid selection of methods to be used, because only a single method for nutritional evaluation is not able to precisely diagnose the alterations in nutritional status.

Several factors can be contributing to the appearance of malnutrition, mainly in the presence of cholestasis, such as hypermetabolism, lipid malabsorption and fat-soluble vitamins. The results found by PIERRO et al. ${ }^{(33)}$ suggest that the hypermetabolism is the main determinant of malnutrition in children with BA.

In the present study, we verified that the serum levels of vitamins $\mathrm{A}$ and $\mathrm{E}$ change according to the patients age, showing that the control group patients with age $\leq 3$ years old showed the lowest levels of these vitamins. In accordance with $\mathrm{OLSON}^{(31)}$, youngish children are more sensible to vitamin A deficiency because the vitamin A storage in newly born and young children is lower than in adults, and the cell growth and differentiation during the first 2 years of life is very intensive. According to this author, the retinol plasmatic levels in humans moderately increase with age. The author MACHILIN ${ }^{(20)}$ declares that children generally have low blood tocopherol levels in comparison to adults due to have lower plasmatic levels of lipids. Thus, children are more sensible to vitamin E deficiency than adults. Due to these conclusions, nutritional status has been estimated by the relation between the vitamin $\mathrm{E}$ and total lipid content in the plasma.

Deficits in serum levels of vitamins A, D and $\mathrm{E}$ were observed in patients with BA and $\mathrm{AIH}$, together or separated, when compared with the control group. These results indicate that BA and AIH diseases may interfere with absorption processes, transport, metabolism and storage of fat-soluble vitamins, which may produce deficiency of these vitamins.

After cholecalcipherol (vitamin $\mathrm{D}_{3}$ ) ingestion, micellar solubilization occurs in the duodenum in the presence of biliary salts, and the absorption occurs along jejuni. Then, the vitamin is incorporated to the kilomicrons, responsible for the transport of vitamin $\mathrm{D}_{3}$ from the lymphatic system to the circulation, which is bounded to the retinol binding protein (RBP) and then conduced to the liver. The first hydroxylation occurs in the liver, generating the intermediary 25 -hydroxyl-cholecalcipherol, which is transformed into the active form of vitamin by subsequent hydroxylation in the kidneys, resulting in the active form of 1,25-dihydroxicalcipherol ${ }^{(32)}$.
In the present study, vitamin $\mathrm{D}$ was monitored in cholecalcipherol form (vitamin $\mathrm{D}_{3}$ ). The cause of low serum concentration of this vitamin in patients with BA and AIH may be related to the processes of absorption and transport of the vitamin until liver.

There are several studies in the literature that relate the presence of low blood levels of vitamins A, E and D in patients with CLD and cholestasis ${ }^{(5,12,13,17)}$. According to the study conducted by FLOREANI et al. ${ }^{(13)}$, the plasmatic levels of retinol, $\alpha$-tocopherol and carotenoids were significantly lower in the CLD group with cholestasis (primary biliary cirrhosis and primary sclerosing cholangitis) than in the control group.

In another study conducted by FERANCHAK et al. ${ }^{(12)}$, it was verified that the vitamin A deficiency is relatively frequent in children with CLD and cholestasis, being proposed that the serum retinol could be used as an initial parameter to monitor the vitamin A deficiency in children with CLD. The authors BASTOS and SILVEIRA ${ }^{(5)}$ verified that the plasmatic levels of vitamin D presented significant difference between patients with cholestasis and the control patients. On the other hand, the vitamin E deficiency was described by GUGGENHEIM et al. ${ }^{(17)}$, who found low serum levels of vitamin $E$ in patients with chronic cholestasis before vitamin $\mathrm{E}$ treatment. These authors recommend the intramuscular therapy with $\alpha$-tocopherol for patients with chronic cholestasis, affirming that the patients can not reach a normal serum concentration of vitamin $\mathrm{E}$ using oral therapy.

In our study, it was not observed significant difference of serum levels of vitamins A, D and E between the BA groups with cholestasis and without cholestasis. This result may be due to the sample being reduced or due to the rigid control for use of vitamins in patients with cholestasis. However, in the study conducted by FERANCHAK et al. ${ }^{(12)}$, there were no significant differences in the serum levels of vitamins $\mathrm{A}, \mathrm{D}$ and $\mathrm{E}$ when comparing the CLD patients with cholestasis and without cholestasis.

Regarding correlations between vitamin content and anthropometric index of patients together, it was verified correlation between vitamin A content and weight/age, midarm circumference, triceps skinfold thickness, subscapular skinfold thickness and midarm fat area, and between vitamin E content and all indexes. These anthropometric indexes were directly correlated with the serum levels of vitamins A and E. Therefore, as the anthropometric measure decreases, the serum levels of these vitamins decrease too.

This positive correlation may suggest that the hepatic disease would lead to the malnutrition status and then to produce fat-soluble vitamin deficiency. Another hypothesis would be that hepatic disease conduces to the fat-soluble deficiency by mechanism previously mentioned. This last hypothesis is the more provable because in AIH the median of Z-score values of the anthropometric variables follow the normality levels, while most patients with AIH presented deficiency of vitamins A, D and $\mathrm{E}$. It is probable that the deterioration of nutritional status cause severity of the vitamin deficiency.

The biliary atresia group presented a direct correlation of triceps skinfold thickness and midarm circumference indexes with serum levels of vitamin A, while the group of autoimmune hepatitis presented correlation of the skinfold sum index with this vitamin. The weight/age and midarm circumference 
indexes in biliary atresia group and midarm muscle area index in autoimmune hepatitis group were directly correlated with serum levels of vitamin E.

In this study, the parameter midarm circumference deserve attention due to their correlations with the vitamins in the groups together and separately, probably because these parameters are the most sensible indicators for nutritional status.

Regarding to the disease severity, the highest anthropometric deficits in our study were detected by weight/age, body mass index, midarm circumference, triceps skinfold thickness and subscapular skinfold thickness parameters in patients with BA classified in Child B + Child C. The disease severity interferes with the nutritional status, leading to the depletion of adipose and muscular mass. Patients with Child B + Child C have the highest nutritional deficits. In patients with AIH classified in Child B + Child C was not noted difference in nutritional status in comparison to patients Child A, once the number of patients was reduced. Only one patient was classified as Child C, while the classification Child B had five patients.

Due to hepatic damage, the patients with cirrhosis can develop protein-caloric malnutrition, which is characterized by depletion in fat storage or in muscle mass ${ }^{(23,35)}$. The detection of protein-caloric malnutrition is very important for nutritional support applications, decreasing infections, clinical complications and mortality.

In the study carried out by MAIO et al. ${ }^{(23)}$, the midarm circumference was the best anthropometric index to relate the muscle mass deficiency with seriousness of hepatic disease severity. However, the BMI and weight indexes should be applied with caution, because the extra cellular fluids can be increased, even in patients with cirrhosis without ascites.

In Table 6, we could verify that the lipid percentile in diet was higher than $30 \%$ in the BA group. Probably, this percentage is related with the supplementation, which is applied in the form of medium chain triglycerides (MCT) modulus in theses patients, mainly in those with cholestasis. AIH patients rarely received supplementation, because most do not present cholestasis. Thus, the objective of nutritional therapy includes the rehabilitation of alterations of body composition and nutritional deficits, prevention of hepatic cell injury, promotion of hepatic regeneration and improvement in the transplant recuperation ${ }^{(16)}$.

The recommended energy intake in well compensated CLD should be with $15 \%-17 \%$ of energy from protein, $20 \%-25 \%$ from fat and the remainder $(60 \%-65 \%)$ from carbohydrate ${ }^{(30)}$. In this study, it is observed that the median of BA and AIH group did not reach the recommendation for carbohydrate and exceeded for lipids.

The energy adequated to the CLD was lower in patients with AIH $(56.2 \%)$ that in patients with BA $(86.80 \%)$. Thus, a higher malnutrition percentage would be expected in patients with AIH, fact that was not occurred in the present study. Two hypotheses may be used to explain this phenomenon: the metabolic expense of this patient has been superestimated or the malnutrition was subdiagnosed, due to use of corticoids that could superestimate the weight. This last hypothesis is less probable because some anthropometric indexes would be not influenced by discreet retention of liquids.

In patients with BA, the energetic expense in repose is about $30 \%$ greater than in normal children of same sex and age ${ }^{(33)}$. Respecting patients with $\mathrm{AIH}$, the studies show the recommendations of energetic necessities are scarce, for this reason was used the energetic adequacy with increase of $30 \%$, according to BAVDEKAR et al. ${ }^{(6)}$.

It is possible to conclude that patients with BA, mainly with cholestasis, present the highest nutritional damage. The patients with BA and AIH presented lower serum levels of vitamins A, D and E that in control group. There is a directly proportional correlation, mainly between vitamin $\mathrm{E}$ and all anthropometric variables of $\mathrm{AB}$ and $\mathrm{AIH}$ groups together. The midarm circumference was the most sensible indicator to correlate the serum levels of vitamins $\mathrm{A}$ and $\mathrm{E}$ in the patients group with BA and $\mathrm{AIH}$. Therefore, we recommend the accompaniment of nutritional status in patients with BA, mainly with cholestasis, to detect early the malnutrition and to adequate the dietary intake of nutrients.

Saron MLG, Godoy HT, Hessel G. Estado nutricional de pacientes com atresia biliar e hepatite autoimune e relação com os níveis séricos de vitaminas A, D e E. Arq Gastroenterol. 2009;46(1): 62-8.

RESUMO - Contexto - As doenças hepáticas crônicas podem induzir à má absorção de lipídios e vitaminas lipossolúveis e levar ao comprometimento do estado nutricional. Objetivos - Avaliar o estado nutricional e relacionar com os níveis séricos de vitaminas (A, D e E) e a gravidade da doença em pacientes com atresia biliar e hepatite autoimune na faixa etária pediátrica. Métodos - O estudo foi transversal controlado e foram avaliados os pacientes com hepatite autoimune e atresia biliar e um grupo controle pareado por sexo e idade. Foi realizada avaliação antropométrica, aplicação do inquérito alimentar e determinação dos níveis séricos das vitaminas A, D e E pela técnica de cromatografia líquida de alta eficiência. Foram empregados os testes de Mann-Whitney, o coeficiente de correlação de Spearman e análise de variância (ANOVA), sendo considerada diferença significativa se $P<0,05$. Resultados - O déficit nutricional mais grave foi observado nos pacientes com atresia biliar, principalmente com colestase. Em relação às vitaminas, no grupo controle, constatou-se que os níveis séricos das vitaminas A e E variaram com a idade. Os níveis séricos das vitaminas A, D e E foram maiores no grupo controle em relação aos pacientes com atresia biliar e hepatite autoimune em conjunto ou separadamente. Verificou-se a correlação do peso/idade, prega cutânea tricipital, prega cutânea subescapular, circunferência braquial, área adiposa braquial com a vitamina $\mathrm{A}$ e de todos os indicadores antropométricos com a vitamina $\mathrm{E}$ nos pacientes com hepatite autoimune e atresia biliar em conjunto. Conclusões - Os pacientes com atresia biliar e colestase apresentaram o maior comprometimento nutricional. Os pacientes com atresia biliar e hepatite autoimune possuíram menores níveis séricos das vitaminas A, D e E do que o grupo controle. Existe uma correlação diretamente proporcional, principalmente da vitamina $\mathrm{E}$ com todos as variáveis antropométricas do grupo de $\mathrm{AB}$ e HAI em conjunto.

DESCRITORES - Estado nutricional. Vitaminas lipossolúveis. Atresia biliar. Hepatite autoimune. Criança. 


\section{REFERENCES}

1. Allagille D. Prolonged obstructive jaundice including calculous and noncalculous gallbladder conditions. In: Roy CC, Silverman A, Allagille D, editors. Pediatric clinical gastroenterology. 4th edition. St. Louis: Mosby; 1995. p.636-65.

2. Alvarez F, Berg PA, Bianchi FB, Bianchi L, Burroughs AK, Cancado EL, Chapman RW, Cooksley WGE, Czaja AJ, Desmet VJ, Donaldson PT, Eddleston ALWF, Fainboim L, Heathcote J, Homberg JC, Hoofnagle JH, Kakumu S, Krawitt EL, Mackay IR, MacSween RNM, Maddrey WC, Manns MP, McFarlane IG, Meyer zum Büschenfelde KH, Mieli-Vergani G, Nakanuma Y, Nishioka M, Penner E, Porta G, Portmann, Reed WD, Rodes J, Schalm SW, Scheuer PJ, Schrumpf E, Seki T, Toda BG, Tsuji T, Tygstrup N, Vergani D, Zeniya M. International Autoimmune Hepatitis Group Report: review of criteria for diagnosis of autoimmune hepatitis. J Hepatol. 1999;31:929-38.

3. Amédée-Manesme O, Furr HC, Alvarez F, Hadchouel M, Alagille D, Olson JA Biochemical indicators of vitamin A depletion in children with cholestasis. Hepatology. 1985;6:1143-8

4. Balistreri WF, Grand R, Hoofnagle JH, Suchy FJ, Ryckman FC, Perlmutter DH, Sokol RJ. Biliary atresia: current concepts and research directions. Hepatology. 1996;23:1682-92.

5. Bastos MD, Silveira TR. Níveis plasmáticos de vitamina D em crianças e adolescentes com colestase. J Pediatr (Rio J). 2003;79:245-52.

6. Bavdekar A, Bhave S, Pandit A. Nutrition management in chronic liver disease. Indian J Pediatr. 2002;69:427-31.

7. Center for Disease Control (CDC). Growth charts: United States. National Center for Health Statistics (NCHS). 2000;314:1-27.

8. Daniel WW. Biostatistics: a foundation for analysis in the health science. 2nd ed New York: Wiley; 1978. p.215-23.

9. Desmet VJ, Gerver M, Hoofnagle JH, Manns M, Scheuer PJ. Classification of chronic hepatitis: diagnosis, grading and staging. Hepatology. 1994;19:1513-20.

10. Dietary reference intakes: energy, carbohydrate, fiber, fat, cholesterol, protein and amino acids. Washington DC: National Academic Press; 2002.

11. Dwyer JT. Dietary assessment. In: Shils ME, Olson JA, Shiker M, editors. Modern nutrition in health and disease. 8th edition. Philadelphia: Williams \& Wilkins; 1994. 195p.

12. Feranchak AP, Gralla J, King R, Ramirez RO, Corkill M, Narkewicz MR, Sokol RJ. Comparison of indices of vitamin A status in children with chronic liver disease. Hepatology. 2005;42:782-92

13. Floreani A, Baragiotta A, Martines D, Naccarato R, D'odorico A. Plasma antioxidant levels in chronic cholestatic liver diseases. Aliment Pharmacol Ther. 2000;14:353-8.

14. Frisancho AR. New norms of upper limb fat and muscles areas for assessment of nutritional status. Am J Clin Nutr. 1981;34:2540-5.

15. Frisancho AR. Anthropometric standards for the assessment of growth and nutritional status. Ann Arbor, MI: University of Michigan; 1989. 189p.

16. Greer R, Lehnert M, Lewindon P, Cleghorn GF, Shepherd RW. Body composition and components of energy expenditure in children with end-stage liver disease. J Pediatr Gastroenterol Nutr. 2003;36:358-63.

17. Guggenheim MA, Ringel SP, Silverman A, Grabert BE. Progressive neuromuscular disease in children with chronic cholestasis and vitamin E deficiency: diagnosis and treatment with alpha tocopherol. J Pediatr. 1982;100:51-8

18. Henkel AS, Buchman AL. Nutritional support in patients with chronic liver disease Nat Clin Pract Gastroenterol Hepatol. 2006;3:202-9.

19. Lohman TG, Roche AF, Martorell R. Anthropometric standardization reference manual. Abridged edition. Champaign: Human Kinetics Books; 1988. 90p.

20. Machlin LJ. Vitamin E. In: Machlin LJ. Handbook of vitamins. New York: Marcel Dekker; 1991. p.99-144.
21. Maggiore G, Bernard O, Homberg JC, Hadchouel M, Alvarez F, Hadchouel P, Odièvre M, Alagille D. Liver disease associated with anti-liver-kidney michrosome antibody in children. J Pediatr. 1986;108:399-404.

22. Maio R, Dichi JB, Burini RC. Conseqüências nutricionais das alterações metabólica dos macronutrientes na doença hepática crônica. Arq Gastroenterol. 2000;37:52-7.

23. Maio R, Dichi JB, Burini RC. Sensibilidade de indicadores da desnutrição protéicoenergética em cirróticos com vários graus de disfunção hepatocelular. Arq Gastroenterol. 2004;41:93-9.

24. Makin E, Davenport M. Biliary atresia. Curr Paediatr. 2006;16:59-63.

25. Matos C, Porayko MK, Francisco-Ziller N, DiCecco S. Nutrition and chronic liver disease. J Clin Gastroenterol. 2002;35:391-7.

26. Mattar RHGM, Azevedo RA, Speridião PGL, Fagundes-Neto U, Morais MB. Estado nutricional e absorção intestinal de ferro em crianças com doença hepática crônica com e sem colestase. J Pediatr (Rio J). 2005;81:317-24.

27. Moyer V, Freese DK, Whitington PF, Olson AD, Brewer F, Colletti RB, Heyman MB Guideline for the evaluation of cholestasis jaundice in infants: recommendations of the North American Society for Pediatric Gastroenterology, Hepatology and Nutrition. J Pediatr Gastroenterol Nutr. 2004;39:115-28.

28. Nobili V. Nutritional considerations in children with chronic liver disease. J. Gastroenterol Hepatol. 2005;20:1805-6.

29. Novy M, Schwarz, KB. Nutrition considerations and management of the child with liver disease. Nutrition 1997;13:177-84.

30. Okita M. Chronic hepatic disease and dietary instruction. Hepatol Res. 2004;30s: s90-s3.

31. Olson JA. Vitamin A. In: Machlin LJ, editor. Handbook of vitamins. New York: Marcel Dekker; 1991. p.1-58.

32. Penteado MV. Vitaminas: aspectos nutricionais, bioquímicos, clínicos e analíticos Barueri, SP: Manole; 2003. p.75-120.

33 Pierro A, Koletzko B, Carnielli V, Superina R, Roberts EA, Filler RM, Smith J, Heim $\mathrm{T}$. Resting energy expenditure is increased in infants and children with extrahepatic biliary atresia. J Pediatr Surg. 1989;24:534-8.

34. Protheroe SM. Feeding the child with chronic liver disease. Nutrition. 1998;14 798-800.

35. Riley TR, Bhatti AM. Preventive strategies in chronic liver disease: Part II. Cirrhosis. Am Family Phys. 2001;64:1735-40

36. Siegel S. Estatística não paramétrica. São Paulo: Makron Books do Brasil Editora; 1975. p.67-240.

37. Silveira TR, Pires ALG. Icterícia colestática neonatal. In: Wehba J, Penna J, FagundesNeto U, editores. Gastroenterologia pediátrica. 2 $2^{\mathrm{a}}$ edição. Rio de Janeiro: MEDSI; 1991. p.465-87.

38. Sokol RJ, Stall C. Anthropometric evaluation of children with chronic liver disease. Am J Clin Nutr. 1990;52:203-8.

39. Taylor RM, Dhawan A. Assessing nutritional status in children with chronic liver disease. J Gastroenterol Hepatol. 2005;20:1817-24.

40. Thakur MI, Srivastava US. Vitamin-E metabolism and its application. Nutr Res. 1996;16:1767-809.

41. Vajro P, Hadchouel P, Hadchouel M, Bernard O, Allagille D. Incidence of cirrhosis in children with chronic hepatitis. J. Pediatr. 1990;117:417-8.

42. Wang LH, Huang SH. Determination of vitamins A, D, E, and K in human and bovine serum, and $\beta$-carotene and vitamin A palmitate in comestic and pharmaceutical products, by isocratic. Chromatographia. 2002;55:289-96. 